九州大学学術情報リポジトリ

Kyushu University Institutional Repository

\title{
Bonus without a Reason: The Minimum Level of Price Premium Required to Shift Wheat Producers' Behaviour
}

\section{Takahashi, Taro}

Graduate School of Agricultural and Life Sciences, The University of Tokyo

Okada, Kensuke

Graduate School of Agricultural and Life Sciences, The University of Tokyo

Suzuki, Nobuhiro

Graduate School of Agricultural and Life Sciences, The University of Tokyo

Maeda, Koshi

Laboratory of Quantitative Food Economic Analysis, Division of Agricultural and Resource Economics, Department of Agricultural and Resource Economics, Faculty of Agriculture, Kyushu University

https://doi.org/10.5109/26180

出版情報: 九州大学大学院農学研究院紀要. 58 (1)，pp.191-193，2013-02. Faculty of Agriculture， Kyushu University

バージョン :

権利関係 : 


\title{
Bonus without a Reason: The Minimum Level of Price Premium Required to Shift Wheat Producers' Behaviour
}

\author{
Taro TAKAHASHI ${ }^{1}$, Kensuke OKADA ${ }^{1}$, Nobuhiro SUZUKI ${ }^{1}$ \\ and Koshi MAEDA* \\ Laboratory of Quantitative Food Economic Analysis, Division of Agricultural and \\ Resource Economics, Department of Agricultural and Resource Economics, \\ Faculty of Agriculture, Kyushu University, Fukuoka 812-8581, Japan \\ (Received October 31, 2012 and accepted November 8, 2012)
}

\begin{abstract}
The publicly funded quality bonus scheme in Japanese wheat market provides the government with a unique opportunity for mechanism design to attract high-quality grains, although the present level of bonus is said to be too low to induce changes in producers' behaviour. Based on the production functions formulated and estimated to explain both the yield and the protein content of hard wheat, this study derives the minimum level of quality bonus required to induce domestic producers to target quality rather than quantity, a shift required so that the quality of domestic grains becomes comparable to that of imported commodities. The result suggests that a bonus of $¥ 70,000$ per tonne is required to change producers’ behaviour, casting a doubt on the effectiveness of the current scheme set at $¥ 31,167$ per tonne.
\end{abstract}

Key words: hard wheat, mechanism design, protein content, quality bonus

\section{INTRODUCTION}

Japan relies $92 \%$ of its wheat consumption on import from Australia (1.0 Mt), Canada (1.0 Mt excluding durum wheat) and the United States (3.2 Mt). Of the 8\% produced domestically, more than $90 \%$ are soft wheat used for noodle flour, the type of wheat only Australia is currently producing outside of the country.

The free trade agreement currently being negotiated between Japan and Australia, if signed, will likely see an influx of inexpensive and high quality soft wheat such as cultivars Calingiri, Binnu and Arrino from Western Australia, where a further production shift from hard wheat used for bread flour, barley, legumes and canola to soft wheat can be achieved effortlessly (Takahashi, 2009). Because such an expansion of import is expected to leave the majority of domestic soft wheat production unsustainable, it would be prudent, particularly from the standpoint of food security, to explore policy options that can induce domestic production of high-quality hard wheat that is comparable to well-regarded imported commodities.

Japan's publicly funded quality bonus scheme for domestically produced wheat provides the nation's policymakers with a unique opportunity for mechanism design. In theory, the government can simultaneously set the quality specifications and the level of bonus payment so that production of grains with desired traits is stimulated. In practice, however, the scheme exercises only a minimal level of influence on producers' behaviour. While the lack of an optimised mechanism is in part attributable to the fact that an agronomically sound hard wheat production system is yet to be established for most parts

\footnotetext{
${ }^{1}$ Graduate School of Agricultural and Life Sciences, The University of Tokyo

* Corresponding author (E-mail: kmaeda@agr.kyushu-u.ac.jp)
}

of the country (Kiribuchi-Otobe et al., 2009), an improvement in the scheme would better prepare producers and wider rural communities for the possible change in the industry landscape.

Based on production functions estimated from the authors' own field experiment growing a hard wheat variety, this study derives the minimum level of quality bonus required to shift wheat producers' behaviour towards the quality enhancement. A particular attention is paid to the relationship between the grain yield and its protein content, the latter of which has been identified as the weakest trait of Japanese hard wheat compared with foreign substitutes such as the Canadian variety of Western Red Spring (Shimazaki and Watanabe, 2010).

\section{MATERIALS AND METHODS}

\section{Field experiment}

The field experiment growing the hard wheat cultivar Yumeshihou was carried out at the experimental field in the city of Nishi Tokyo (35 $\left.44^{\prime} \mathrm{N}, 1^{\circ} 39^{\circ} 32^{\prime} \mathrm{E}\right)$ between October 2010 and June 2011. While biological traits of the cultivar have previously been studied (Kato and Yamagishi, 2011; Kato, 2012), its economic viability has not been investigated until recently (Takahashi and Okada, 2012).

Twenty-four plots of $24 \mathrm{~m}^{2}$ each were assigned to 8 treatments by the split-split plot design with 3 replications. The treatments covered the full factorial combination of 2 sowing time and 4 levels of nitrogen fertilisation. The early sowing group was sown on 2 November and the late sowing group on 1 December, both by the direct drilling method. The levels of nitrogen fertilisation included 0, 80, 110 and $140 \mathrm{~kg} \mathrm{ha}^{-1}$. Ammonium sulphate with $21 \%$ nitrogen content was used as nitrogen fertiliser. The sowing rate was fixed at $80 \mathrm{~kg} \mathrm{ha}^{-1}$ with the row interval of $0.19 \mathrm{~m}$. All plots were fertilised pre-sowing 
with phosphorus (at $93 \mathrm{~kg} \mathrm{ha}^{-1}$ ) and potassium (at $70 \mathrm{~kg}$ $\left.\mathrm{ha}^{-1}\right)$.

The early sowing group was harvested on 15 June and the late sowing group on 22 and 23 June. At harvest, the grain yield $\left(\mathrm{t} \mathrm{ha}^{-1}\right)$ at $12.5 \%$ moisture was recorded. In addition, the grains from each plot were chemically analysed by the Dumas method for their protein content (\%) at $13.5 \%$ moisture.

Using the yield and protein content data obtained from this experiment, two equations explaining the yield and the grain protein content were estimated using the ordinary least squares method. Simultaneous equations methods such as seemingly unrelated regressions were not necessitated because the independent variables of the equations were identical (Amemiya, 1985). The equations were:

$$
\begin{aligned}
y= & 2.67+.022 n+\varepsilon_{1} \quad\left(R^{2}=.6498\right), \text { and } \\
& \quad(.33)(.0036) \\
p= & 10.60+.028 n+\varepsilon_{2}\left(R^{2}=.6180\right), \\
& \quad(.42)(.004)
\end{aligned}
$$

where $y$ is the yield $\left(\mathrm{t} \mathrm{ha}^{-1}\right), p$ is the grain protein content (\%), $n$ is the level of nitrogen fertilisation $\left(\mathrm{kg} \mathrm{ha}^{-1}\right)$, and the numbers in the parentheses beneath estimators are standard errors. The residuals $\varepsilon_{1}$ and $\varepsilon_{2}$ show the correlation efficient of -0.21 , a result consistent with the commonly held view that the yield and the protein content of wheat are negatively correlated (Theobald and Talbot, 2004; Farquharson et al., 2008). These residuals were jointly tested for bivariate normality using the Shapiro-Wilk method, where the null hypothesis of normality was not rejected $(W=.94 ; p=.28)$.

\section{Economic model}

Based on the results of the field experiment, the economically optimal level of nitrogen application under various levels of quality bonus was computed. For a given level of quality bonus, producers were assumed to maximise their expected profit per hectare of operation defined by the following expression:

$$
\mathrm{E} \pi=\iint y(\bar{a}+b) d y d p-\bar{c}_{n} n-\bar{c}_{o},
$$

where $a$ is a portion of wheat price that is unrelated to the grain quality, $b$ the publicly funded quality bonus linked to the grain protein content $(p), c_{n}$ the cost of nitrogen fertiliser, and $c_{o}$ all other cost incurred from the operation. The exogenous values $a, c_{n}$ and $c_{o}$ were taken from the literature and fixed throughout the analysis (Table 1). The double integral includes both yield and protein content, which were assumed to be uncertain to producers ex ante, but to be known to follow Equations (1) and (2). The random part of the equations was assumed to follow the bivariate normal distribution with the covariance matrix constructed from the residuals $\varepsilon_{1}$ and $\varepsilon_{2}$ obtained from the field experiment.

The values $y$ and $p$ were simultaneously drawn for
Table 1. Exogenous parameters used in the analysis

\begin{tabular}{lrc}
\hline Parameter & \multicolumn{1}{c}{ Value } & Source \\
\hline$a\left(¥ \mathrm{t}^{-1}\right)$ & 58,340 & MAFF (2012) \\
$c_{n}\left(¥ \mathrm{~kg}^{-1}\right)$ & 2,480 & Institute for Fertilizer Marketing (2012) \\
$c_{o}\left(¥ \mathrm{ha}^{-1}\right)$ & 292,980 & MAFF (2012) \\
\hline
\end{tabular}

one million times to emulate the prescribed distribution, which is analytically unintegrable. For each given level of quality bonus, this process was repeated with varied $n$, over the agronomically realistic range between $0 \mathrm{~kg} \mathrm{ha}^{-1}$ and $150 \mathrm{~kg} \mathrm{ha}^{-1}$, in order to find the economic optimum.

Following the actual bonus scheme, a quality bonus of $¥ 150,000$ per tonne ${ }^{1}$ was paid if the realised $p$ was within the range desired by flour mills or between $11.5 \%$ and $14 \%$. For grains not satisfying this criterion, a 'consolation bonus' of a less value was paid. The difference between these two values was thus called the price premium. The optimisation problem was solved under a varied levels of price premium, between the maximum amount paid under the present scheme or $¥ 31,167$ per tonne $^{2}$ and the theoretically maximum level or $¥ 150,000$ per tonne. Finally, the distribution of the grain protein content at these optima was compared using Equation (2).

\section{RESULTS AND DISCUSSION}

Under the present price premium, the operation is optimised at $n=150$ (Table 2), where only $22 \%$ of grains satisfy the quality specifications (Fig. 1). This result suggests that the current level of quality bonus is too low to work as an incentive to control the nitrogen content of grains. Instead, producers target a high yield regardless of the grain quality, as the benefit of producing a large quantity outweighs that of producing good quality grains. This finding makes a stark contrast to the Canadian quality bonus system, which has been estimated to shift producers' nitrogen input by 60\% (Smith et al., 2003).

In order to make farmers quality-conscious, a minimum price premium of $¥ 70,000$ is required. At this level, the operation is optimised at $n=130$ with $39 \%$ of grains satisfying the quality specifications. As the price premium increases from $¥ 70,000$, the level of nitrogen input

Table 2. Solutions to producers' optimisation problem

\begin{tabular}{cc}
\hline Quality premium $\left(¥ \mathrm{t}^{-1}\right)$ & Nitrogen input $\left(\mathrm{kg} \mathrm{ha}^{-1}\right)$ \\
\hline$-60,000$ & $150+$ \\
70,000 & 130 \\
80,000 & 120 \\
$90,000-100,000$ & 110 \\
$110,000-140,000$ & 100 \\
150,000 & 90 \\
\hline
\end{tabular}

1 This corresponds to the bonus for grains ranked 1A under the present scheme.

2 This corresponds to the price premium enjoyed by $1 \mathrm{~A}-$ ranked grains relative to 2D-ranked grains under the present scheme. 


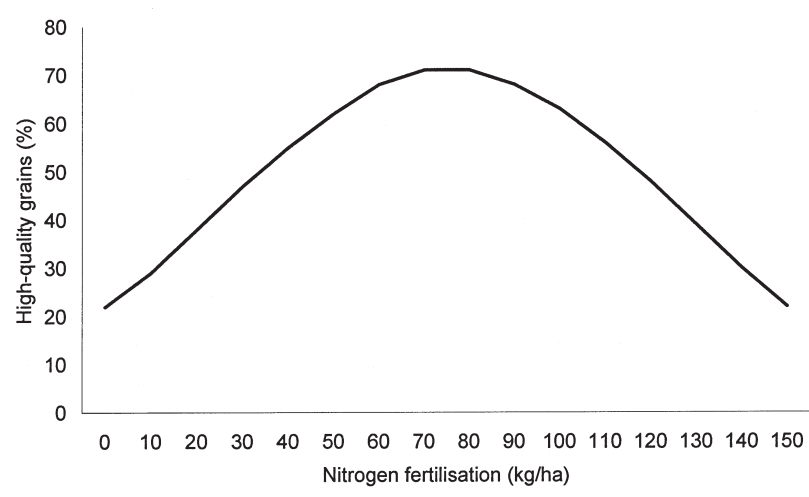

Fig. 1. Proportion of high-quality grains.

decreases and the quality of grains improves. With the price premium of $¥ 150,000,90 \mathrm{~kg}$ per hectare of nitrogen is used and $68 \%$ of grains have the protein content desired by processors.

Agronomically, the largest proportion or $71 \%$ of grains satisfy the quality target when $n=80$. Taken together with a previous finding that the agronomically optimal fertilisation regimes differ considerably depending on whether to target a high yield or an ideal level of protein content (Nakano and Morita, 2009), this result suggests that the protein target should be set slightly below the actually desired level because, irrespective of the value of quality bonus, producers have an incentive to apply more fertiliser and gain from quantity rather than quality.

The finding that at maximum more than $70 \%$ of domestically produced grains can be quality-comparable to imported grains is encouraging in the light of Japan's declining food self-sufficiency. It is worthwhile noting, however, that such competitiveness can only be achieved at the governmental expenditure in excess of the present maximum quality bonus, or $¥ 150,000$ per tonne. Thus, the result of this study reiterates the importance to consider the cost of maintaining the quality of domestic products at the evaluation of potential free trade agreements.

\section{REFERENCES}

Amemiya, T. 1985 Advanced Econometrics. Harvard University Press, Cambridge

Farquharson, R. J., Cacho, O. J., Mullen, J. D. and Schwenke, G. D. 2008 An economic approach to soil fertility management for wheat production in north-eastern Australia. Agr. Econ., 38: 181-192

Institute for Fertilizer Marketing 2012 Farmgate Price of Fertilizers. http://www.hi-kei-ken.jp/hiryou

Kato, Y. 2012 Grain nitrogen concentration in wheat grown under intensive organic manure application on andosols in Central Japan. Plant Prod. Sci., 15: 40-47

Kato, Y. and Yamagishi, J. 2011 Long-term effects of organic manure application on the productivity of winter wheat grown in a crop rotation with maize in Japan. Field Crop Res., 120: 387-395

Kiribuchi-Otobe, C., Seki, M., Matsunaka, H., Yoshioka, T., Fujita, M., Yanagisawa, T. and Yoshida, H. 2009 Breeding Yumeshiho, a new bread wheat cultivar. Bull. Nat Inst. Crop Sci., 10: 75-88

MAFF 2012 Outlook on Demand and Supply of Wheat. http:// www.maff.go.jp/j/seisan/boueki/mugi_zyukyuu

Nakano, H. and Morita, S. 2009 Effects of seeding rate and nitrogen application rate on grain yield and protein content of the bread wheat cultivar Minaminokaori in southwestern Japan. Plant Prod. Sci., 12: 109-115

Shimazaki, Y. and Watanabe, Y. 2010 Grain protein concentration of wheat (T. aestivum L.): can cultivation techniques control the grain protein concentration of wheat? Jpn. J. Crop Sci. 79: $407-413$

Smith, E. G., McKenzie, R. H. and Grant, C. A. 2003 Optimal input use when inputs affect price and yield. Can. J. Agr. Econ., 51: 1-13

Takahashi, T. 2009 Report to MAFF on Australian Wheat Production and Export. http://www.maff.go.jp/j/kokusai/ kokusei/kaigai_nogyo/k_syokuryo/h20

Takahashi, T., and Okada, K. 2012 Economic feasibility of hard wheat and soft wheat production systems in Eastern Japan. Jpn. J. Crop Sci., 81S2: 206-207

Theobald, C.M. and Talbot, M. 2004 Bayesian selection of fertilizer level when crop price depends on quality. Comp. Stat. Data Anal., 47: 867-880 